\title{
Mitigation Of Climate Change Of Coffee Production Systems In Cundinamarca, Colombia
}

\author{
Hernán J. Andrade ${ }^{1}$ (D), Piedad C. Zapata² \\ ${ }^{1}$ Grupo de Investigación PROECUT, Facultad de Ingeniería Agronómica, Universidad del Tolima - UT, Ibagué/Tolima, Colombia \\ ${ }^{2}$ Grupo de Investigación Agrícola Sostenible-The Nature Conservancy, Bogotá D.C., Colombia
}

\begin{abstract}
Production systems with woody perennial plants, ideally timber trees, are technologies accepted in carbon (C) projects to mitigate climate change. This research had as purpose the estimation of $\mathrm{C}$ storage and fixation in coffee production systems in Cundinamarca, Colombia. Carbon in biomass, necromass and soil were estimated in coffee plantations with three different shade levels (low, medium and high) in three municipalities using IPCC's recommendations. Soil stored 75\% of the total C (93.9 to $137.7 \mathrm{Mg} \mathrm{C} \mathrm{ha}^{-1}$ in the upper $30 \mathrm{~cm}$ ), followed by trees (19\%). Carbon increases with a rise in shade (55.8 vs $42.0 \mathrm{vs} 23.0 \mathrm{Mg} \mathrm{C} \mathrm{ha}^{-1}$ for high, medium and low shade, respectively). These coffee plantations fixed a mean of $2.3 \mathrm{MgC} \mathrm{ha}^{-1} \mathrm{year}^{-1}$, with a maximum value of $7.1 \mathrm{Mg} \mathrm{CO}_{2} \mathrm{ha}^{-1}$ year $^{-1}$ under a shade of $30 \%$ to $40 \%$. Coffee plantations, especially with high shade, have a high potential of $\mathrm{C}$ fixation and mitigate climate change.
\end{abstract}

Keywords: agroforestry systems, biomass, dendrometry and forest inventory, forest soils. 


\section{INTRODUCTION}

The increase of global temperature, the generalized glacier melting and therefore, sea level raise, have made evident the drastic changes that endanger the permanence of plant, animal and ecosystem species in the planet (Walther et al., 2002; Bellard et al., 2012). Some of the main causes of these changes are related to deforestation, soil degradation and fossil fuels usage, which increase greenhouse effect gases (GHG) in the atmosphere (IPCC, 2006; Andrade et al., 2013a). This situation has caused the planning of strategies to mitigate such effects on the planet, such as source reduction (Emission Rights Commerce and Joint Implementation) and the increase of sinks (Clean Development Mechanisms - CDM) (Pearson et al., 2005). The last one includes strategies for the adequate land use, such as agroforestry systems (AFS) like coffee with perennial wood species, which helps in carbon (C) capturing and reducing GHG emission (Albrecht \& Kandji, 2003; Soto-Pinto et al., 2010; Andrade et al., 2014a).

The coffee crop is of high importance for Colombia. Around 563,000 families economically depend on this activity and it generates over 726,000 rural jobs. Nowadays, the country produces around $1,086,000$ sacks of green coffee, thus contributing with $1 \%$ of national GDP and $11.6 \%$ of agricultural GDP, locating it over other crops such as banana and flowers (FNC, 2015). Coffee growing also contains a very little explored potential as climate change mitigation mechanism, via environmental service of $\mathrm{C}$ capture. Countries like Costa Rica, pioneers in providing such services, serve as a model to generate investment projects that will help fixating $\mathrm{C}$ in biomass and soil, by promoting AFS with coffee or other species.
The goal of this study was to estimate the potential of climate change mitigation of coffee (Coffea arabica L.) production systems with contrasting levels of shade in the municipalities of Pacho, San Juan de Rioseco and Tibacuy, Cundinamarca, Colombia.

\section{MATERIALS AND METHODS}

\subsection{Area of study}

The study was carried out in 45 coffee-producing farms, 15 in each of the municipalities of this study: Pacho, San Juan de Rioseco and Tibacuy, in the department of Cundinamarca. Five farms were selected by shade level (low, medium and high) in every municipality, according to the abundance of timber or fruit trees that accompany coffee (var. Castillo) and the level of shade that they projected (Table 1). Every sampling unit corresponded to a coffee lot with ages between 2.5 and 6 years in Pacho and San Juan, and 4 to 8 years in Tibacuy.

\subsection{Estimation of carbon components}

Three components of the $\mathrm{C}$ storage were estimated: biomass (above- and bellowground), necromass and soil organic C (SOC). Aboveground biomass was estimated in a rectangular temporary sampling plot of $1000 \mathrm{~m}^{2}$ per repetition where the trunk diameter at breast height (dbh) was measured and total height (th) of all trees with $\mathrm{dbh} \geq 10 \mathrm{~cm}$. In every main plot, two $5 \times 5 \mathrm{~m}$ nested sub-plots were established in opposing corners where th and trunk diameter at $15 \mathrm{~cm}$ high $\left(d_{15}\right)$ were measured in every coffee bush. Aboveground biomass of the individual plants was estimated using

Table 1. General features of study municipalities in Cundinamarca, Colombia.

\begin{tabular}{|c|c|c|c|c|c|c|}
\hline \multirow{2}{*}{ Municipality/Location } & Mean altitude & Mean rainfall & Yearly mean & \multicolumn{3}{|c|}{ Shade (\%) } \\
\hline & $(\mathrm{m})$ & $\left(\mathrm{mm}\right.$ year $\left.^{-1}\right)$ & $\left({ }^{\circ} \mathrm{C}\right)$ & Low & Medium & High \\
\hline \multicolumn{7}{|l|}{ Pacho } \\
\hline $\begin{array}{l}5^{\circ} 02^{\prime} 18.2^{\prime \prime}-5^{\circ} 17^{\prime} 44.8^{\prime \prime} \mathrm{N} \\
74^{\circ} 02^{\prime} 19.8^{\prime \prime}-74^{\circ} 18^{\prime} 9.2^{\prime \prime} \mathrm{W}\end{array}$ & 1800 & 1670 & 18 & $0-30$ & $31-36$ & $37-52$ \\
\hline \multicolumn{7}{|l|}{ San Juan de Rioseco } \\
\hline $\begin{array}{l}4^{\circ} 43^{\prime} 31.8^{\prime \prime}-4^{\circ} 58^{\prime} 40.8^{\prime \prime} \mathrm{N} \\
74^{\circ} 33^{\prime} 54.9^{\prime \prime}-74^{\circ} 46^{\prime} 8.3^{\prime \prime} \mathrm{W}\end{array}$ & 1303 & 1313 & 20 & $0-30$ & $31-63$ & $64-75$ \\
\hline \multicolumn{7}{|l|}{ Tibacuy } \\
\hline $\begin{array}{l}4^{\circ} 15^{\prime} 41.5^{\prime \prime}-4^{\circ} 23^{\prime} 13.4^{\prime \prime} \mathrm{N} \\
74^{\circ} 25^{\prime} 13.4^{\prime \prime}-74^{\circ} 33^{\prime} 19.3^{\prime \prime} \mathrm{W}\end{array}$ & 1649 & 1403 & 19 & $0-20$ & $21-47$ & $48-70$ \\
\hline
\end{tabular}


allometric models by species or life zones generated by several authors (Table 2). In the case of species without specific biomass allometric models, general models that included $\mathrm{dbh}$, th, biomass expansion factor (BEF) and specific gravity (SG) were employed. The SG was obtained from global database (Zanne et al., 2009) or using the default $0.6 \mathrm{~g} \mathrm{~cm}^{-3}$ for the rest of species that is recommended for the tropical America by IPCC (2006). Biomass underground was estimated using the model proposed by Cairns et al. (1997) (Table 2).

Necromass was estimated with methods specifically for dead wood (fallen and standing) and litter. Fallen dead wood (diameter $\geq 10 \mathrm{~cm}$ ) was estimated by line transects method: two perpendicular lines of $50 \mathrm{~m}$ each located in the center of the main plot, where the diameter of each piece that intercepts the line was measured (IPCC, 2006). A specific gravity was assigned to each piece according to its hardness: hard, medium and soft $\left(0.6,0.4\right.$ and $0.2 \mathrm{~g} \mathrm{~cm}^{-3}$, respectively), which was considered according to the specific gravity in accordance with the floristic composition of the tree strata. Standing dead wood was estimated in the main plot using the methods for timber volume calculations, BEF or biomass models with correction due to the inexistent biomass fraction compared to live trees of the same species. Litter was estimated by weighing fresh all dead material (diameter $<10 \mathrm{~cm}$ ) found in ten frames of $50 \times 50 \mathrm{~cm}$ each, distributed randomly along the main plot and taking a subsample of $\sim 200 \mathrm{~g}$ to estimate dry matter ( $65^{\circ} \mathrm{C}$ until constant weight).

SOC was estimated at a depth of 0 to $30 \mathrm{~cm}$ considering bulk density (BD), SOC concentration and the proportion of thick fragments (diameter $>2 \mathrm{~mm}$ ). Soil BD was estimated with the cylinder method
(5 $\mathrm{cm}$ in height and $5 \mathrm{~cm}$ in diameter), in three places per plot. SOC concentration was calculated by taking randomly 10 subsamples along the whole plot with an auger, which were later homogenized to have a composed sample to analyze by the Walkley \& Black (1934) method. Thick fragment proportion was estimated with a $50 \times 50 \times 50 \mathrm{~cm}$ pit per plot, from which all such material with that size was extracted and estimated by water displacement using volumetric containers.

Carbon in biomass and necromass was estimated multiplying the dry matter by the recommended fraction (0.5) and then converting it to $\mathrm{CO}_{2}$ e using the constant of 3.67 (IPCC, 2006). Total C fixation in biomass was calculated dividing its storage in total biomass between age. Potential impact of a shade level change on the $\mathrm{C}$ fixation in total biomass of every municipality was estimated. This was calculated as a $3 \times 3$ matrix corresponding to all possible changes of shade level, without considering the municipality. The intersections are considered as the effect of these changes. Positive values correspond to increases on fixation rate, while negative ones indicate reductions, which lead to GHG emissions.

\subsection{Data analysis}

Variance analyses were carried out using the completely randomized design with three treatments and five repetitions per municipality, after testing the assumptions. The differences between treatments in every municipality were analyzed by Fisher LSD test at $5 \%$ probability. All statistical analyses were carried out with the software Infostat.

Table 2. Allometric models to estimate above and bellowground biomass of trees in coffee plantations of Cundinamarca, Colombia.

\begin{tabular}{|c|c|c|}
\hline Species & Model & Source \\
\hline \multicolumn{3}{|c|}{ Aboveground biomass } \\
\hline Coffea arabica & $\operatorname{Ln}(B)=-1.92+0.95 * \operatorname{Ln}\left(d_{15}\right)+1.42 * \operatorname{Ln}($ th $)$ & Andrade et al. (2016) \\
\hline Cordia alliodora & $\log (B)=-0.755+2.072^{\star} \log (\mathrm{dbh})$ & \multirow{2}{*}{ Segura et al. (2006) } \\
\hline Inga spp & $\log (B)=-0.834+2.223^{\star} \log (d b h)$ & \\
\hline Fruit-growing (multi-species) & $\log (B)=-1.11+2.64^{\star} \log (d b h)$ & Andrade et al. (2008) \\
\hline Other timber species (Multi-species) & $\log (B)=-8.78722+1.69001^{\star} \operatorname{Ln}($ th $)$ & Aristizábal (2011) \\
\hline \multicolumn{3}{|c|}{ Bellowground biomass } \\
\hline Multi-species & $\operatorname{Ln}(B B)=-1.0587+0.8836^{\star} \operatorname{Ln}(\mathrm{AB})$ & Cairns et al. (1997) \\
\hline
\end{tabular}

B: aboveground biomass $\left(\mathrm{kg}_{\text {plant }}{ }^{-1}\right) ; \mathrm{d}_{15}$ : trunk diameter at $15 \mathrm{~cm}$ height $(\mathrm{cm})$; th: total height $(\mathrm{m})$; dbh: trunk diameter chest-height (cm), Log: 10-base logarithm; Ln: natural logarithm; BB: belowground biomass ( $\left.\mathrm{Mg} \mathrm{ha}^{-1}\right) ; \mathrm{AB}$ : aboveground biomass $\left(\mathrm{Mg} \mathrm{ha}^{-1}\right)$. 


\section{RESULTS AND DISCUSSION}

\subsection{Carbon storage components}

Most of the C storage in the systems was located in the soil (75\%). These AFS stored a mean of 161.8 $\mathrm{Mg} \mathrm{C}^{-1}$ with some differences between shade levels: 149.5 vs 161.7 vs $174.2 \mathrm{Mg} \mathrm{C} \mathrm{ha}^{-1}$ for low, medium and high shade, respectively (Figure 1). The highest values found in medium shade are possibly due to the species used in the upper stratum, which could have higher timber volume, biomass and $\mathrm{C}$ because of being timber and at the same time generate less shade. Andrade et al. (2014b) state that in coffee crops shade canopy influenced notoriously in $\mathrm{C}$ storage. These values are greater than those of coffee crops in Guatemala, which were estimated in 127.6 $\mathrm{Mg} \mathrm{C} \mathrm{ha}^{-1}$ (Schmitt-Harsh et al., 2012). But they are very similar to $161.3 \mathrm{Mg} \mathrm{C} \mathrm{ha}^{-1}$ in AFS with different shade settings in Mexico (Soto-Pinto \& Aguirre-Dávila, 2015). Van Rikxoort et al. (2014) also found that traditional multiple crops contain much more $\mathrm{C}$ in biomass than monocultures (42.5 vs $10.5 \mathrm{Mg} \mathrm{C} \mathrm{ha}^{-1}$, respectively).

The same pattern of $\mathrm{C}$ storage distribution was observed in the three shade levels, given that trees were the second most important component (19\% of total); while the other $\mathrm{C}$ sinks stored between just between $1.2 \%$ and $2.0 \%$ of the total. Coffee production systems in Tibacuy stored more $\mathrm{C}$ in biomass and necromass than those in San Juan and Pacho (49.5 vs 42.9 vs $28.4 \mathrm{Mg} \mathrm{ha}^{-1}$, respectively) (Figure 1a).

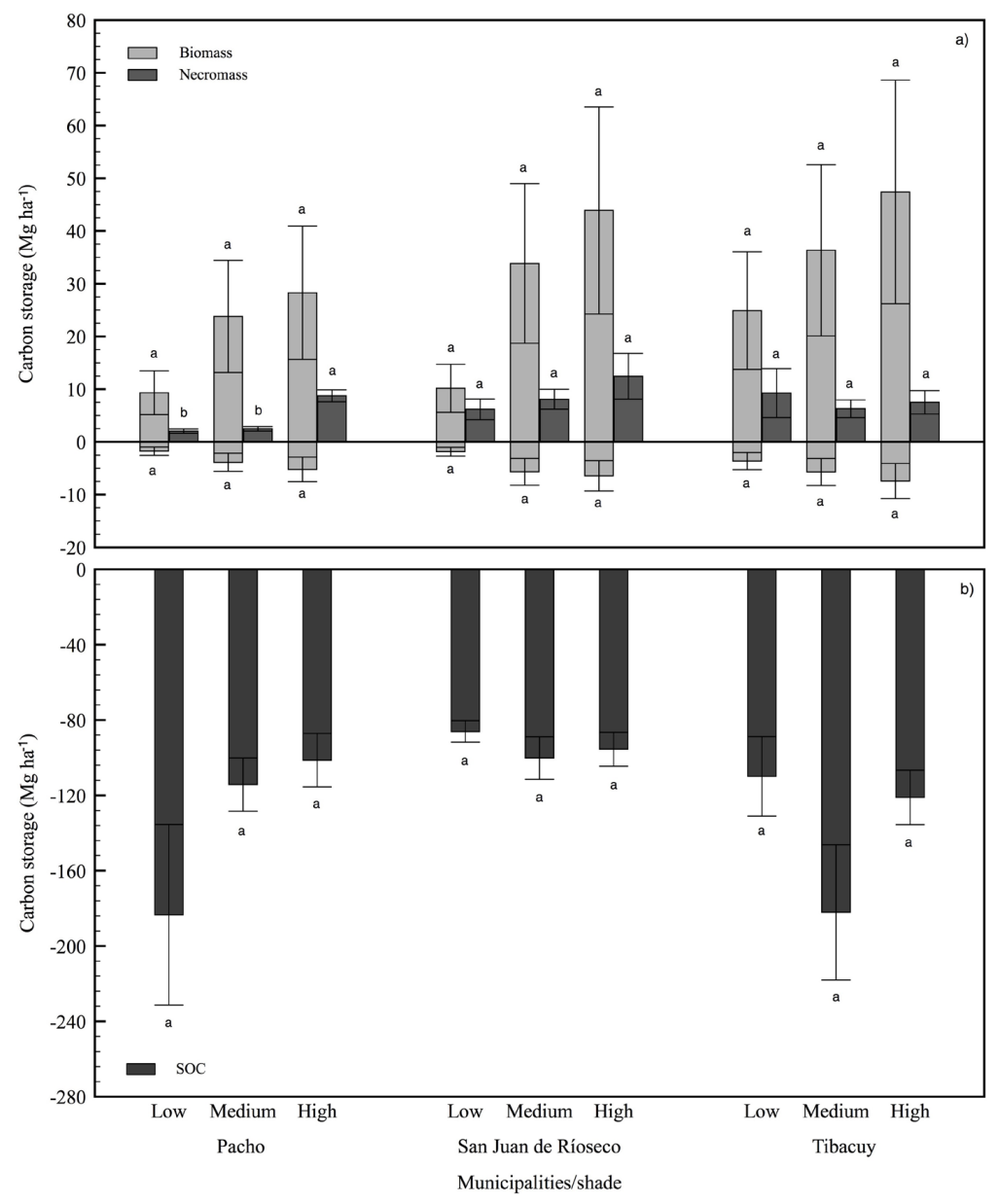

Figure 1. Carbon storage in biomass and necromass (a) and soil organic carbon (SOC) at a 0 to $30 \mathrm{~cm}$ depth (b) in coffee production systems in three municipalities of Cundinamarca, Colombia. Bars with negative values represent bellowground biomass and soil organic carbon (SOC). Error bars correspond to the mean standard error. Bars with different letters indicate statistical differences $(\mathrm{p}<0.05)$ among shade levels by municipality. 
Trees captured, on average, $77 \%$ of the total of C in biomass and necromass. Although there were no statistical differences $(p>0.05)$ in $C$ between shade levels, $\mathrm{C}$ storage raised with the increase of shade: the coffee systems with high shade captured $55.8 \mathrm{Mg} \mathrm{ha}^{-1}$, which is $33 \%$ and $143 \%$ greater than medium and a low shade, respectively (Figure 1a). This behavior is related with the abundance and type of tree species associated to each system, because these store a large amount of C in biomass (Andrade et al., 2014b).

Coffee bushes that contributed with $6 \%$ of total C in biomass and necromass, with some non-significant differences ( $p>0.05$ ) between municipalities: in Pacho, they stored more $\mathrm{C}$ than in Tibacuy and San Juan (2.0 vs 1.8 vs $1.2 \mathrm{Mg} \mathrm{ha}^{-1}$, respectively). However, the three municipalities showed totally different tendencies in this sink. In Pacho, significant differences $(\mathrm{p}<0.05)$ were detected between systems: 3.1 vs 1.6 vs $1.2 \mathrm{MgCha}^{-1}$ for high, medium and low shade, respectively. In San Juan and Tibacuy statistical differences $(p>0.05)$ were not found. Apparently, these variations of $\mathrm{C}$ in coffee bushes occur primarily due to factors such as plantation age and management rather than shade level. Ávila et al. (2001) found a C storage of $1.2 \mathrm{Mg} \mathrm{C} \mathrm{ha}^{-1}$ in coffee systems associated with Eucalyptus spp. in Costa Rica, which are congruent with the findings with low shade in Pacho and medium shade in Tibacuy. Andrade et al. (2014b) estimated a C storage of $2.2 \mathrm{Mg} \mathrm{C} \mathrm{ha}^{-1}$ in a 3.5-years coffee monoculture in Líbano, Tolima; values higher than those of this current study.

Carbon stored in bellowground biomass varied between $13 \%$ and $16 \%$ of the captured by the aboveground component (Figure 1a). These numbers are totally discordant with those reported by Andrade et al. (2014a), who state that coffee plants in Tolima store their biomass underground soil $50 \%$ of what is found aboveground. Frequently, the biomass component of roots is discarded from $\mathrm{C}$ inventories in AFS, ignoring a possible potential of 10 and $40 \%$ of total contribution, depending on the climate (Andrade \& Ibrahim, 2003). These studies gave a key information for the inclusion of this component in $\mathrm{C}$ projects.

Necromass was the less important C component, given that it stored only between $1 \%$ and $6 \%$ of the total (Figure 1a). It was detected a statistical effect $(\mathrm{p}<0.05)$ of the shade level in this sink, finding the greatest values in high shade (6.0 $\mathrm{Mg} \mathrm{ha}^{-1}$ ), exceeding 35\% and $82 \%$ those of low and medium shade, respectively.
This tendency was clearly observed in Pacho and San Juan de Ríoseco because $C$ in this sink was rising as shade increased, while in Tibacuy the tendency was the opposite (Figure 1a). In the same way, significant differences $(p<0.05)$ were detected between the municipalities, given that coffee production systems from San Juan and Tibacuy stored 60\% more C in their necromass in comparison with Pacho (Figure 1a). $\mathrm{C}$ in this component has presented a high variety of values. For example, Callo-Concha et al. (2002) and Espinoza-Domínguez et al. (2012) report values under 1.9 $\mathrm{Mg} \mathrm{ha}^{-1}$. In contrast, Mena et al. (2011) found 2.1 to $2.9 \mathrm{Mg} \mathrm{ha}^{-1}$ in Costa Rica. Leaf litter is related to tree density and their species, particularly foliage biomass (Prescott, 2002), and play a major role in the dynamic of $\mathrm{C}$ and nutrients in the generation of environmental services and adaptation of land use systems to climate change (Andrade et al., 2013b).

SOC was the main sink in these coffee production systems, since it stored between $60 \%$ and $93 \%$ of the total (86.1 to $183.4 \mathrm{Mg} \mathrm{ha}^{-1}$ in the upper $30 \mathrm{~cm}$ of the soil) (Figure 1b). No significant differences ( $p>0.05$ ) were found among the shade levels of the three municipalities studied. However, soils of Tibacuy and Pacho stored much more $\mathrm{C}$ than in Tibacuy (137.7 vs 132.9 vs 93.9 $\mathrm{Mg} \mathrm{ha}^{-1}$, respectively) (Figure $1 \mathrm{~b}$ ). In Pacho, SOC was higher in low shade than in medium and high (183.3, 114.2 and 101.3 $\mathrm{Mg} \mathrm{Cha}^{-1}$, respectively), which contrasted with San Juan de Rioseco and Tibacuy, where the highest SOC occurred in medium shade, followed by high and low for last (100.2 vs 95.5 vs 86.1 and 182.1 vs 121.1 vs $109.9 \mathrm{Mg} \mathrm{ha}^{-1}$ for San Juan and Tibacuy, respectively). No direct relation was found in $\mathrm{C}$ in necromass and SOC, thus showing the importance of other soil determining factors such as parental material, the weather, handle and history of the soil (Bockheim \& Hartemink, 2017). In contrast, Tumwebaze \& Byakagaba (2016) state that AFS with coffee in Uganda has more SOC than those coffee plantations without trees (54.4 vs $51.4 \mathrm{Mg} \mathrm{C} \mathrm{ha}^{-1}$, respectively).

Andrade et al. (2008) found similar results also in AFS with cocoa ( $50 \%$ and $40 \%$ for SOC and clump biomass, respectively). These results show the importance of the shade canopy in C storage, since cocoa plantations are commonly grown with more shadow tan coffee plantations (Beer et al., 1998; Schroth et al., 2001). Ávila et al. (2001) reported values of $108.6 \mathrm{Mg} \mathrm{C} \mathrm{ha}^{-1}$ in coffee AFS with Eucalyptus spp., data close to the 
ones obtained in the medium shade system. C storing range in these AFS with coffee, without including SOC, was 13.1 to $62.8 \mathrm{Mg} \mathrm{ha}^{-1}$, values that can be compared to the $\mathrm{C}$ stocks in secondary forests and intervened primary forests (Brown, 1997).

\subsection{Total carbon storing in coffee plantations}

Coffee plantations in three municipalities showed differences in carbon capture: in Tibacuy, they had $16 \%$ and $37 \%$ more than in Pacho and San Juan de Ríoseco (187.2 vs 161.5 vs $136.8 \mathrm{Mg} \mathrm{Cha}^{-1}$, respectively) (Figure 2). However, different tendencies occurred in the three municipalities. In San Juan de Ríoseco, shade increase raised carbon stock; while in Pacho, the tendency was the opposite; and in Tibacuy there was no clear pattern by having the highest carbon stored in coffee plantations with medium shade (Figure 2). The results suggest that the abundance of tree species that accompany AFS and according to there are for timber or service, affect $C$ storing in soil as said by several authors (Andrade et al., 2014b; Somarriba et al., 2013). Results indicate that here is no direct relation between floristic composition and shade $\mathrm{C}$ fixation rates (Isaac et al., 2007; Häger, 2012). This means there can be other species that may offer high shade but do not contribute in a significant way with this environmental service.

\subsection{Carbon Fixation in total biomass}

Coffee production systems fix $\mathrm{C}$ in total biomass at an average rate of $2.3 \mathrm{Mg} \mathrm{C} \mathrm{ha}^{-1}$ year $^{-1}$ (0.9 a 5.3 $\mathrm{MgC} \mathrm{ha}^{-1}$ year $\left.^{-1}\right)$, with a few differences between municipalities: 1.8 vs 2.1 vs $3.0 \mathrm{Mg} \mathrm{C} \mathrm{ha}^{-1}$ year $^{-1}$ for San Juan, Pacho and Tibacuy, respectively (Figure 2). In the same way, there were significant differences $(\mathrm{p}<0.05)$ in coffee fixation rates in every system, where an increasing $\mathrm{C}$ fixation was detected as shade was increased in the AFS of Pacho and San Juan de Ríoseco: maximum in high shade $\left(2.7 \mathrm{MgC} \mathrm{ha}^{-1}\right.$ year $\left.^{-1}\right)$, which surpassed in $23 \%$ and $130 \%$ systems with medium and low shade, respectively (Figure 2). In Tibacuy, $\mathrm{C}$ fixation in biomass presented the same tendency than storage: higher in medium shade than in high and low (6.2 vs 2.7 vs $1.8 \mathrm{Mg} \mathrm{C} \mathrm{ha}^{-1}$ year $^{-1}$ ). These values are congruent with those of $2.7 \mathrm{Mg} \mathrm{C} \mathrm{ha}^{-1}$ year $^{-1}$ estimated by Segura \& Andrade (2012). On the other hand, Oelbermann et al. (2004) and Hergoualc'h et al. (2012) in Costa Rica, and Andrade et al. (2014a) in Colombia showed that AFS with coffee fix more C than in monoculture.

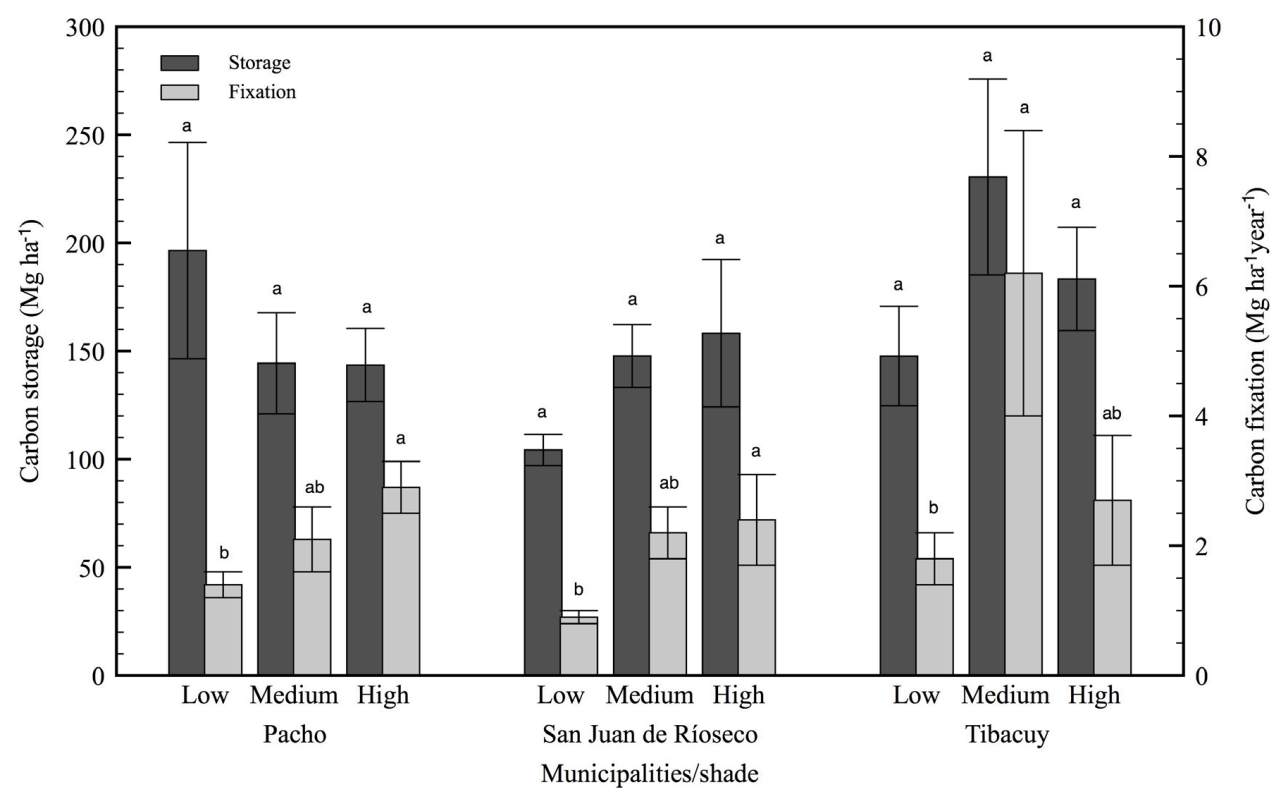

Figure 2. Total carbon storage and fixation rate in total biomass in coffee production systems in three municipalities of Cundinamarca, Colombia. Error bars correspond to mean standard error. Bars with different letters indicate statistical differences $(\mathrm{p}<0.05)$ among shade levels by municipality. Carbon stored in soil refers to a 0 to $30 \mathrm{~cm}$ depth. 
Trees in AFS with medium shade in Tibacuy presented rates very similar to those estimated by Andrade et al. (2014a) in coffee plantations with C. alliodora in Líbano, Tolima (4.9 $\mathrm{Mg} \mathrm{C} \mathrm{ha}^{-1}$ year $^{-1}$ ). In Pacho and San Juan de Rioseco, the highest $\mathrm{C}$ fixation rate in trees occurred in the high shade system followed by medium and low shade: 2.0 vs 1.6 vs $0.6 \mathrm{Mg} \mathrm{C} \mathrm{ha}^{-1}$ year $^{-1}$, respectively (Figure 2). These contributions in $\mathrm{C}$ fixation systems are related to age, abundance and composition of shade canopy (Somarriba et al., 2013). Segura \& Andrade (2012) reported C fixation values in trees in coffee plantations under different certification standards (4.2 a $11.8 \mathrm{Mg} \mathrm{C} \mathrm{ha}^{-1}$ year $^{-1}$ ), which are really higher than those found in Cundinamarca's coffee plantations. Andrade et al. (2014b) found a C fixation in AFS highly dependent of the shade canopy composition: 3.6 and 1.2 $\mathrm{Mg} \mathrm{C} \mathrm{ha}^{-1}$ year $^{-1}$ for Cordia alliodora and Hevea brasiliensis, respectively. Similar results were reported by Marín et al. (2016) in AFS with cocoa in Tolima, Colombia.

The highest $\mathrm{C}$ fixation rates in biomass were reached in medium shade systems, followed by high and low level shade (3.2 vs 2.5 vs $1.3 \mathrm{Mg} \mathrm{C} \mathrm{ha}^{-1} \mathrm{year}^{-1}$ ). In coffee plants, the highest $\mathrm{C}$ fixation in biomass in Pacho was found in high shade $\left(0.9 \mathrm{Mg} \mathrm{C} \mathrm{ha}^{-1}\right.$ year $\left.^{-1}\right)$, which was $33 \%$ greater than in low and medium shade. The highest fixation rate in coffee bushes in San Juan was found in low shade $\left(0.6 \mathrm{Mg} \mathrm{C} \mathrm{ha}^{-1} \mathrm{year}^{-1}\right)$, even though medium shade stored more $\mathrm{C}$ in this component (1.6 Mg C ha-1 year-1), without significant difference $(p>0.05)$. In Tibacuy, coffee AFS with low shade fixed $C$ at a rate similar to high shade, but these were significantly superior $(\mathrm{p}<0.05)$ to medium shade (0.5 vs 0.4 vs $0.3 \mathrm{Mg} \mathrm{C} \mathrm{ha}^{-1}$ year $^{-1}$, respectively). Biomass and $\mathrm{C}$ of woody perennial crops is affected by the shade canopy features, as proven by Isaac et al. (2007).

These findings are congruent with other authors' estimates, with slight differences. Andrade et al. (2014a) found values slightly higher in AFS with C. alliodora in Líbano, Tolima, Colombia (0.6 to $0.8 \mathrm{Mg} \mathrm{C} \mathrm{ha}^{-1}$ year $^{-1}$ ); whereas Ávila et al. (2001) found fixation rates of $0.4 \mathrm{Mg} \mathrm{C} \mathrm{ha}^{-1}$ year $^{-1}$ in AFS with coffee at semi-shade in Costa Rica, which is similar to what was found here. Segura \& Andrade (2012) found lower values in coffee crops associated with trees $\left(0.2 \mathrm{Mg} \mathrm{Cha}^{-1}\right.$ year $\left.^{-1}\right)$, along with Andrade et al. (2014b), who reported a C fixation rate of coffee AFS with Hevea brasiliensis of $0.4 \mathrm{Mg} \mathrm{C} \mathrm{ha}^{-1}$ year-1 $^{-1}$ Carbon fixation in trees, which contributed with $70 \%$ of total biomass, was higher in Ávila et al. (2001) findings: from $0.3 \mathrm{Mg} \mathrm{C} \mathrm{ha}^{-1}$ year $^{-1}$ for coffee in association with poró (Erythrina poepigiana) until 1.1 Mg C ha-1 year ${ }^{-1}$ for coffee associated with eucalyptus (Eucalyptus spp.). Andrade et al. (2014b) reported $C$ fixation values higher than those found in this study for coffee-C. alliodora AFS, but similar in coffee in monoculture or in AFS with plantain; whereas in AFS with rubber, the fixation averages were lower than the ones evaluated here $(5.3,0.7$ and $1.6 \mathrm{Mg} \mathrm{C}$ ha $^{-1}$ year $^{-1}$, respectively).

Shade was more related to storage than fixation rate $(r=0.43$ and $p<0.05$ vs $r=0,15$ and $p=0.31$, respectively) (Figures 3a and $3 \mathrm{~b}$ ). However, tendencies indicate that $\mathrm{C}$ stabilized in $\sim 62 \mathrm{Mg} \mathrm{Cha}^{-1}$ when shade reached $\sim 60 \%$ (Figure $3 \mathrm{~b}$ ). It means that higher shade does not seem to cause positive effects in $\mathrm{C}$ capture in biomass and necromass. On the other hand, at those same levels of shade, $\mathrm{C}$ fixation rate seem to fall slightly ( 2.8 $\mathrm{Mg} \mathrm{C} \mathrm{ha}^{-1}$ year $^{-1}$ ) (Figure 3b) from the maximum value $\left(7.1 \mathrm{Mg} \mathrm{C}^{-1}\right.$ year $^{-1}$ ) reached at shade between $30 \%$ and $40 \%$ (Figure $3 \mathrm{~b}$ ). On this sense, Andrade et al. (2014b) estimated that maximum C fixation in coffee plantations with $C$. alliodora in Líbano, Tolima, Colombia gets to a $33 \%$ of shade, which matches with the recommendations of Federación Nacional de Cafeteros de Colombia.

\subsection{Impact of shade management in carbon fixation}

The potential changes in $\mathrm{C}$ fixation in total biomass due to the effect of alterations in shade level are shown in Table 3. In Pacho and San Juan, the best scenario would be to pass from low shade to high shade, which would increase $\mathrm{C}$ fixation rates in $5.5 \mathrm{Mg} \mathrm{CO}_{2}$ ha $^{-1}$ year $^{-1}$ (Table 3). In Tibacuy, the most positive change in shade would be to increase it from low to medium shade, which would increase fixation in $13.9 \mathrm{Mg} \mathrm{CO}_{2} \mathrm{ha}^{-1}$ year $^{-1}$. In projects of mitigation of climate change through $\mathrm{C}$ capture in land use, land use change and forestry, $\mathrm{C}$ additionality is estimated as the $\mathrm{C}$ capture above those reached in absence of an activity or given project (Valatin, 2011). 

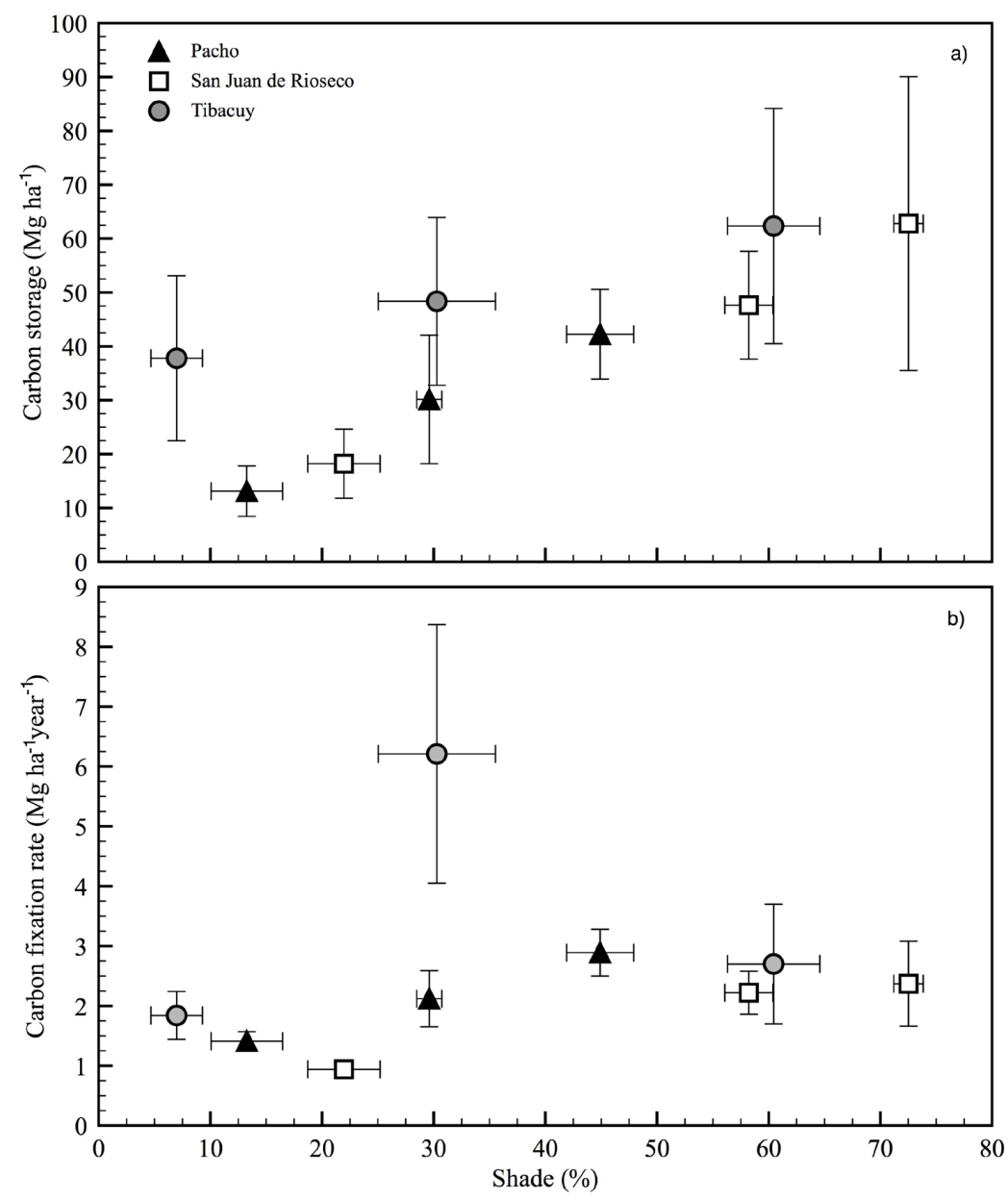

Figure 3. Impact of shade in carbon storage in total biomass and necromass (a) and fixation rate in total biomass (b) in coffee plantations of Cundinamarca, Colombia. Error bars correspond to mean standard error.

Table 3. Effects of potential changes in shade level on atmospheric $\mathrm{C}$ fixation in total biomass in coffee production systems in three municipalities of Cundinamarca, Colombia.

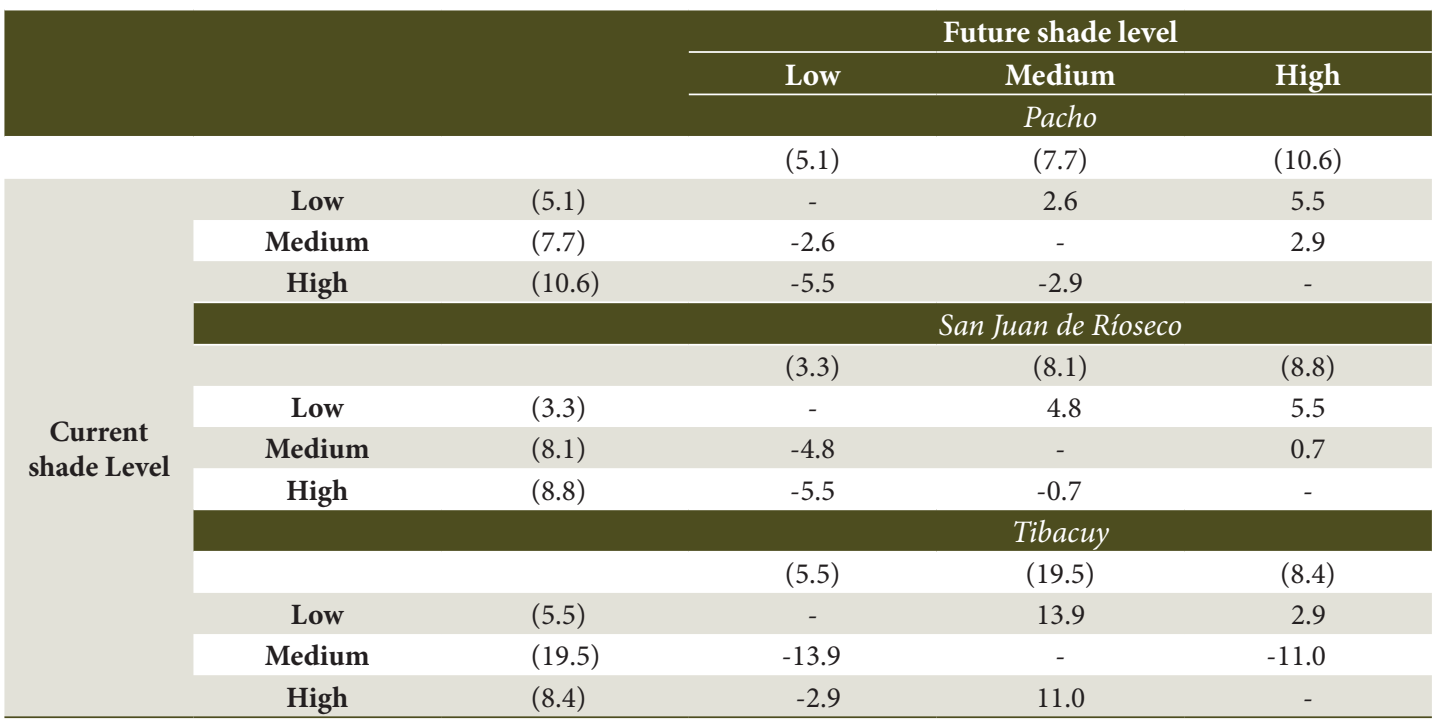




\section{CONCLUSIONS}

Coffee production systems in Pacho, San Juan de Rioseco and Tibacuy present a potential for the mitigation of climate change when capture atmospheric $\mathrm{C}$ in biomass, necromass and soils. The main $\mathrm{C}$ sink was soil, which stored $75 \%$ of the total $\left(121 \mathrm{MgCha}^{-1}\right)$ at a depth of 0 to $30 \mathrm{~cm}$. Trees contributed with $77 \%$ of the total of $\mathrm{C}$ stored in biomass and necromass; whereas this last component had a little contribution to $\mathrm{C}$ storage in coffee plantations ( $1 \%$ to $6 \%$ of total).

Pacho, San Juan and Tibacuy coffee plantations stored in biomass and necromass on average $40.3 \mathrm{Mg} \mathrm{C}$ $\mathrm{ha}^{-1}$, being the AFS with a high shade the greatest sink (55.8 $\mathrm{Mg} \mathrm{Cha}^{-1}$ ), surpassing between 33\% and 143\% medium and low shade, respectively. This indicates the importance of shade canopy in the environmental service of climate change mitigation. AFS with medium shade in Tibacuy showed the highest rates of accumulation of this GHG in biomass (3.6 Mg C ha ${ }^{-1}$ year $\left.^{-1}\right)$.

Increases in the levels of shade in these coffee plantations, changing from low shade to medium shade and high shade, would cause a $\mathrm{C}$ addition between 5.5 and $13.9 \mathrm{Mg} \mathrm{CO}_{2}$ ha $^{-1}$ year $^{-1}$. This shade increase presents an opportunity to fix more $\mathrm{C}$ and grant access to projects of payment for environmental services, which would represent a benefit in livelihoods of local populations.

\section{ACKNOWLEDGEMENTS}

This research was funded by the Department of Cundinamarca by the Sistema General de Regalías Fondo de Ciencia, Tecnología e Innovación, through Convenio 009, 2014, between the Department of Cundinamarca and the Universidad de Ciencias Aplicadas y Ambientales U.D.C.A, with the participation of the Corporación Autónoma Regional de Cundinamarca and the Corporación Latinoamericana Misión Rural. Special thank to the 15 coffee producers for participating in this research.

\section{SUBMISSION STATUS}

Received: 15 mar., 2018

Accepted: 06 jun., 2018

\section{CORRESPONDENCE TO}

\section{Hernán J. Castañeda}

Universidad del Tolima - UT, Barrio Santa

Helena Parte Alta, Zip Code: 730006-299, Ibague, Tolima, Colombia

e-mail: hjandrade@ut.edu.co

\section{FINANCIAL SUPPORT}

Proyecto Regalías - Department of Cundinamarca and the Universidad de Ciencias Aplicadas y Ambientales (Grant/Award Number: Convenio 009, 2014)

\section{REFERENCES}

Albrecht A, Kandji ST. Carbon sequestration in tropical agroforestry systems. Agriculture, Ecosystems \& Environment 2003; 99(1-3): 15-17. http://dx.doi.org/10.1016/S01678809(03)00138-5.

Andrade H, Ibrahim M. ¿Cómo monitorear el secuestro de carbono en los sistemas silvopastoriles? Agroforestería de las Américas 2003; 10(39-40): 109-116.

Andrade H, Marín L, Pachón D. Fijación de carbono y porcentaje de sombra en sistemas de producción de café (Coffea arabica L.) en el Líbano, Tolima. Bioagro- 2014b; 26(2): 127-132.

Andrade HJ, Segura M, Somarriba E, Villalobos M. Valoración biofísica y financiera de la fijación de carbono por uso del suelo en fincas cacaoteras indígenas de Talamanca, Costa Rica. Agroforestería en las Américas 2008; 46: 45-50.

Andrade HJ, Segura MA, Canal DS, Feria M, Alvarado JJ, Marín LM et al. The carbon footprint of coffee productive chains in Tolima, Colombia. In: Oelbermann M, editor. Sustainable Agroecosystems in Climate Change Mitigation. Amsterdam: Wageningen Academic Publishers; 2014a. http://dx.doi.org/10.3920/978-90-8686-788-2_3.

Andrade HJ, Alvarado J, Segura M. Almacenamiento de carbono orgánico en suelos en sistemas de producción de café (Coffea arabica L), en el municipio de Líbano, Tolima. Colombia Forestal 2013a; 16(1): 21-31. http:// dx.doi.org/10.14483/udistrital.jour.colomb.for.2013.1.a02. Andrade HJ, Segura MA, Canal DS, Gómez MJ, Marín MP, Sierra E et al. Estrategias de adaptación al cambio climático en sistemas de producción agrícola y forestal en el Departamento del Tolima. 1st ed. Ibagué: Sello Editorial Universidad del Tolima; 2013b.

Andrade, H. J., Segura, M. A., Feria, M., Suárez, W. Aboveground biomass models for coffee bushes (Coffea arabica L.) in Líbano. Tolima: Agroforestry Systems; 2016. 
Aristizábal J. Desarrollo de modelos de biomasa aérea en sombríos de cafeto (Coffea arabica L) mediante datos simulados. Revista Udca Actualidad \& Divulgacion Cientifica 2011; 14(1): 49-56.

Ávila G, Jiménez F, Beer J, Gómez M, Ibrahim M. Almacenamiento, fijación de carbono y valoración de servicios ambientales en sistemas agroforestales en Costa Rica. Agroforestería en las Américas 2001; 8(30): 32-35.

Beer J, Muschler R, Kass D, Somarriba E. Shade management in coffee and cacao plantations. Agroforestry Systems 1998; 38(1): 139-164.

Bellard C, Bertelsmeier C, Leadley P, Thuiller W, Courchamp F. Impacts of climate change on the future of biodiversity. Ecology Letters 2012; 15(4): 365-377. http://dx.doi. org/10.1111/j.1461-0248.2011.01736.x. PMid:22257223.

Bockheim JG, Hartemink AE. Soil-forming factors. In: Bockheim JG, Hartemink AE, editors. The soils of wisconsin. Cham: Springer; 2017. (World Soils Book Series). http:// dx.doi.org/10.1007/978-3-319-52144-2_3.

Brown S. Estimating biomass and biomass change in tropical forests. Rome: Food and Agriculture Organization of the United Nations; 1997. (Forestry Paper; no. 134).

Cairns MA, Brown S, Helmer EH, Baumgardner GA. Root biomass allocation in the world's upland forests. Oecologia 1997; 111(1): 1-11. http://dx.doi.org/10.1007/ s004420050201. PMid:28307494.

Callo-Concha D, Krishnamurthy L, Alegre J. Secuestro de carbono por sistemas agroforestales amazónicos. Revista Chapingo Serie Ciencias Forestales y del Ambiente 2002; 8(2): 101-106.

Espinoza-Domínguez W, Krishnamurthy L, VázquezAlarcón A, Torres-Rivera A. Almacén de carbono en sistemas agroforestales con café. Revista Chapingo Serie Ciencias Forestales y del Ambiente 2012; 18(1): 57-70. http://dx.doi.org/10.5154/r.rchscfa.2011.04.030.

Federación Nacional de Cafeteros - FNC. Estadísticas históricas [online]. 2015 [cited 2015 feb. 25]. Available from: http://www.federaciondecafeteros.org/particulares/ es/quienes_somos/119_estadisticas_historicas/

Häger A. The effects of management and plant diversity on carbon storage in coffee agroforestry systems in Costa Rica. Agroforestry Systems 2012; 86(2): 159-174. http:// dx.doi.org/10.1007/s10457-012-9545-1.

Hergoualc'h KE, Blanchart E, Skiba U, Henault C, Harmand JM. Changes in carbon stock and greenhouse gas balance in a coffee (Coffea arabica) monoculture versus an agroforestry system with Inga densiflora, in Costa Rica. Agriculture, Ecosystems \& Environment 2012; 148: 102-110. http://dx.doi.org/10.1016/j.agee.2011.11.018.

Intergovernmental Panel on Climate Change - IPCC. Guidelines for national greenhouse gas inventories. Tokio: IGES; 2006.
Isaac ME, Timmer VR, Quashie-Sam SJ. Shade tree effects in an 8-year-old cocoa agroforestry systems: biomass and nutrient diagnosis of Theobroma cacao by vector analysis. Nutrient Cycling in Agroecosystems 2007; 78(2): 155-165. http://dx.doi.org/10.1007/s10705-006-9081-3.

Marín MDP, Andrade HJ, Sandoval AP. Fijación de carbono atmosférico en la biomasa total de sistemas de producción de cacao en el departamento del Tolima, Colombia. Revista Udca Actualidad \& Divulgacion Cientifica 2016; 19(2): 351-360. http://dx.doi.org/10.31910/rudca.v19.n2.2016.89.

Mena V, Andrade H, Navarro C. Biomasa y carbono almacenado en sistemas agroforestales con café y en bosques secundarios en un gradiente altitudinal de Costa Rica. Agroforestería Neotropical 2011; 1: 1-20.

Oelbermann M, Voroney RP, Gordon AM. Carbon sequestration in tropical and temperate agroforestry systems: a review with examples from Costa Rica and southern Canada. Agriculture, Ecosystems \& Environment 2004; 104(3): 359-377. http://dx.doi.org/10.1016/j. agee.2004.04.001.

Pearson T, Walker S, Brown S. Sourcebook for land use, land-use change and forestry projects [online]. 2005 [cited $2015 \mathrm{Jul}$ 30]. Available from http://bit.ly/1VQoZCQ

Prescott CE. The influence of the forest canopy on nutrient cycling. Tree Physiology 2002; 22(15-16): 11931200. http://dx.doi.org/10.1093/treephys/22.15-16.1193. PMid:12414379.

Schmitt-Harsh M, Evans TP, Castellanos E, Randolph JC. Carbon stocks in coffee agroforests and mixed dry tropical forests in the western highlands of Guatemala. Agroforestry Systems 2012; 86(2): 141-157. http://dx.doi. org/10.1007/s10457-012-9549-x.

Schroth G, Lehmann J, Rodrigues MRL, Barros E, Macêdo JLV. Plant-soil interactions in multistrata agroforestry in the humid tropics. Agroforestry Systems 2001; 53(2): 85-102. http://dx.doi.org/10.1023/A:1013360000633.

Segura M, Andrade H. Huella de carbono en cadenas productivas de café (Coffea arabica L.) con diferentes estándares de certificación en Costa Rica. Revista Luna Azul 2012; 35: 60-77.

Segura M, Kanninen M, Suárez D. Allometric models for estimating aboveground biomass of shade trees and coffee bushes grown together. Agroforestry Systems 2006; 68(2): 143-150. http://dx.doi.org/10.1007/s10457-006-9005-x.

Somarriba E, Cerda R, Orozco L, Cifuentes M, Dávila $\mathrm{H}$, Espin $\mathrm{T}$ et al. Carbon stocks and cocoa yields in agroforestry systems of Central America. Agriculture, Ecosystems \& Environment 2013; 173: 46-57. http://dx.doi. org/10.1016/j.agee.2013.04.013.

Soto-Pinto L, Aguirre-Dávila CM. Carbon stocks in organic coffee systems in Chiapas, Mexico. The Journal of Agricultural Science 2015; 7(1): 117-128. 
Soto-Pinto L, Anzueto M, Mendoza J, Ferrer GJ, Jong B. Carbon sequestration through agroforestry in indigenous communities of Chiapas, Mexico. Agroforestry Systems 2010; 78(1): 39-51. http://dx.doi.org/10.1007/s10457009-9247-5.

Tumwebaze SB, Byakagaba P. Soil organic carbon stocks under coffee agroforestry systems and coffee monoculture in Uganda. Agriculture, Ecosystems \& Environment 2016; 216: 188-193. http://dx.doi. org/10.1016/j.agee.2015.09.037.

Valatin G. Forests and carbon: a review of additionality Forestry commission research report. Edinburgh: Forestry Commission; 2011.

Van Rikxoort H, Schroth G, Läderach P, RodríguezSánchez B. Carbon footprints and carbon stocks reveal climate-friendly coffee production. Agronomy for
Sustainable Development 2014; 34(4): 887-897. http:// dx.doi.org/10.1007/s13593-014-0223-8.

Walkley A, Black CA. An examination of the Degtajareff's method for determining soil organic matter and a proposed modification of the chromic acid titration method. Soil Science 1934; 37(1): 29-38. http://dx.doi. org/10.1097/00010694-193401000-00003.

Walther GR, Post E, Convey P, Menzel A, Parmesan C, Beebee TJC et al. Ecological responses to recent climate change. Nature 2002; 416(6879): 389-395. http://dx.doi. org/10.1038/416389a. PMid:11919621.

Zanne AE, Lopez-Gonzalez G, Coomes DA, Ilic J, Jansen $\mathrm{S}$, Lewis SL et al. Global wood density database [online]. Dryad; 2009 [cited 2017 Feb 17]. Available from http:// hdl.handle.net/10255/dryad.235 